\title{
Optimization Study in Biodiesel Production via Response Surface Methodology Using Dolomite as a Heterogeneous Catalyst
}

\author{
Regina C. R. Santos, Rômulo B. Vieira, and Antoninho Valentini \\ Department of Analytical Chemistry and Physical Chemistry, Federal University of Ceará, 60440-554 Fortaleza, CE, Brazil \\ Correspondence should be addressed to Antoninho Valentini; valent@ufc.br
}

Received 24 August 2014; Revised 11 November 2014; Accepted 12 November 2014; Published 30 November 2014

Academic Editor: Vijay Bokade

Copyright (C) 2014 Regina C. R. Santos et al. This is an open access article distributed under the Creative Commons Attribution License, which permits unrestricted use, distribution, and reproduction in any medium, provided the original work is properly cited.

A carbonate mineral, dolomite, was used as a heterogeneous catalyst to produce methyl-esters from soybean oil. The samples were analyzed by XRF, TGA, XRD, TPD- $\mathrm{CO}_{2}$, and SEM. The calcination of dolomite at $800^{\circ} \mathrm{C} / 1 \mathrm{~h}$ resulted in a highly active mixed metal oxides. In addition, the influence of the reaction variables such as the temperature, catalyst amount, and methanol/soybean oil molar ratio in methyl-ester production was optimized by the application of a central composite design in conjunction with the response surface methodology (RSM). The XRF analysis is carried out after the reuses procedure which shows that the deactivation process is mainly due to the selective calcium leaching. Overall, the calcined dolomite exhibited high catalytic activity at moderate operating conditions for biodiesel production.

\section{Introduction}

The increase in the number of publications addressing the topic biodiesel in recent years is noticeable [1]. This is due to the environmental benefits that the biodiesel fuel provides [2]. Conventional biodiesel production is performed through a transesterification reaction of triglycerides with monoalkyl alcohols (i.e., methanol and ethanol) [3]. Homogeneous alkaline catalysts have been widely used since the process produces high amount of methyl-esters in a short reaction time $[4,5]$. In order to solve the problem related to the purification step, solid base catalysts have been considered as an alternative to homogeneous base catalysts $[6,7]$.

Occasionally, the synthesis processes of heterogeneous catalysts can contribute to an additional cost of the final product. However, the use of a simple, safe, and low cost heterogeneous catalyst for the biodiesel production reaction can be effective to an industrial application $[8,9]$.

Dolomite is a natural carbonate mineral typically represented by a stoichiometric chemical composition of $\mathrm{CaMg}\left(\mathrm{CO}_{3}\right)_{2}$ [10]. During the calcinations, the carbonate groups are decomposed generating their respective basic oxides $(\mathrm{MgO}$ and $\mathrm{CaO})[11,12]$. The alkaline oxides $\mathrm{CaO}$ and $\mathrm{MgO}$ are frequently used as heterogeneous catalysts for biodiesel production [13-15]. Therefore, the solid dolomite catalyst, which is an environmentally acceptable material with high basicity and low cost, is possibly an efficient and promising alternative catalyst for biodiesel production.

Several studies [11, 16-20] have reported the use of calcined and/or modified dolomite as a solid catalyst for biodiesel production; however the operating conditions involved a longer reaction time with high methanol/oil ratio and catalyst weight, none of which are commercially attractive features for a catalyst. In order to study the optimum reaction conditions for the catalytic activity of dolomite in transesterification reaction of triglyceride to methyl-esters, a central composite design and a response surface methodology (RSM) were employed. The experimental design and RSM is a useful statistical technique that involves multiple regression analysis and fewer experimental runs for designing experiments, constructing models, evaluating the effects of factors, and analysing the optimum conditions of factors for optimization processing [21, 22]. 
It is known that the catalytic performance is highly dependent of the operating conditions (reaction temperature, catalyst amount, and methanol/oil molar ratio) as well as the temperature heat treatment used in natural dolomitic rock [20]. Thus, a preliminary study of the catalytic activity of dolomite as a function of calcination temperature was also investigated. Furthermore, the structural, textural, surface, and morphological properties of dolomite catalyst were determined to justify their overall catalytic performance, additionally to the chemical analysis in order to detect a composition change due to the reuse process.

\section{Materials and Methods}

2.1. Dolomite Heat Treatment and Characterization. The dolomite used in the present study was obtained from ITAMIL (Itaóca Mineration, located in Fortaleza city, Brazil). Before being used as a catalyst, the dolomite was calcined in a tubular furnace under flowing air for $1 \mathrm{~h}$.

The optimum calcinations temperature was determined by thermogravimetric analysis simultaneously to the differential thermal analysis (TG/DTA), which was performed at a heating rate of $10^{\circ} \mathrm{C} / \mathrm{min}$ under flowing air $(40 \mathrm{~mL} / \mathrm{min})$. Elemental composition analysis was performed on an energydispersive X-ray fluorescence (XRF) spectrometer operating with Pd X-ray tube at $40 \mathrm{kV}$ and $1.2 \mathrm{~mA}$, for semiquantitative analysis of elements with atomic mass greater than or equal to that of fluorine. The crystal structure of the dolomite was characterised by X-ray diffraction (XRD) analysis using $\mathrm{K} \alpha$ Co source $(\lambda=1.788965 \AA)$ at $40 \mathrm{kV}$ and $40 \mathrm{~mA}$, over a $2 \theta$ range of 10 to $90^{\circ}$.

The temperature-programmed desorption of $\mathrm{CO}_{2}$ (TPD$\mathrm{CO}_{2}$ ) was performed under flowing $\mathrm{He}(30 \mathrm{~mL} / \mathrm{min})$ at a heating rate of $10^{\circ} \mathrm{C} / \mathrm{min}$. The catalysts $(200 \mathrm{mg})$ were preheated under flowing $\mathrm{N}_{2}(30 \mathrm{~mL} / \mathrm{min})$ at $800^{\circ} \mathrm{C}$ for $1 \mathrm{~h}$, after which the temperature was decreased to room temperature under flowing $\mathrm{N}_{2}$. A flow of pure $\mathrm{CO}_{2}(30 \mathrm{~mL} / \mathrm{min})$ was subsequently introduced into the reactor for $0.5 \mathrm{~h}$. The flowing $\mathrm{CO}_{2}$ was switched to flowing $\mathrm{He}$, and the temperature program was started after the baseline of an online thermal conductivity detector (TCD) had stabilised. The desorbed $\mathrm{CO}_{2}$ was detected by the same system (TCD) after passing through a trap $\left(-20^{\circ} \mathrm{C}\right)$.

In order to evaluate the textural properties, the samples were analysed by scanning electron microscopy and nitrogen adsorption/desorption isotherms. Prior to the adsorption experiments the calcined sample (180-200 mg) was evacuated at $100^{\circ} \mathrm{C}$ for $2 \mathrm{~h}$.

2.2. Preliminary Study of Dolomite Catalytic Activity in the Transesterification of Soybean Oil. In order to fix the reaction time to be used in the experiments, were carried out catalytic tests were carried out using methanol/oil molar ratio of $6: 1$, reaction temperature of $55^{\circ} \mathrm{C}$, and catalyst loading of 0.6 (wt $\%$ of oil), in different reaction time. A refined deodorised soybean oil with acidity of $0.05 \mathrm{wt} \%$ (as oleic acid), moisture oil of $0.11 \% \mathrm{wt}$, a density at $20^{\circ} \mathrm{C}$ of $0.9237 \mathrm{~kg} / \mathrm{L}$, and a kinematic viscosity of $30.1 \mathrm{~mm}^{2} / \mathrm{s}\left(40^{\circ} \mathrm{C}\right)$ was used as reactant.
The contents were charged into a $250 \mathrm{~mL}$ three-neck round-bottom flask equipped with a reflux condenser, and the reaction mixtures were magnetically stirred. The reaction temperature was controlled by a hotplate, utilizing an oil bath. Following, the desired catalyst amount was activated in a tubular furnace under $\mathrm{N}_{2}$ flow and immediately added into the reaction mixture.

At the end of each test, the catalyst was separated by centrifugation, and the mixture was transferred to a decanting funnel for phase separation. Following, the glycerine phase was separated, and the less-dense phase, which contains the methyl-ester mixture, was then loaded into a rotary evaporator to remove the excess of methanol. The methylester content was analysed by gas chromatography using an instrument equipped with a FID detector and a nonpolar capillary column. The content of the FAME that is expressed in terms of weight percentage was calculated based on the standard method EN 14103 in the presence of methyl laurate as an internal standard [23].

2.3. Design of Experiments and Optimization Method. The response surface methodology (RSM) has already proven to be a reliable statistical tool in the investigation of chemical treatment processes to optimize parameters with a minimal number of experiments [24]. Accordingly, in this study a central composite design (CCD) and RSM was used to investigate the effect of the parameters on the dolomite catalyst activity for biodiesel production and to obtain a good model equation to predict the optimum FAME yield conditions. The factors selected for the optimization of the dolomite activity in transesterification reaction of soybean oil to esters were reaction temperature, catalyst amount, and methanol/oil molar ratio. Then, a set of 17 experiments, which included the $2^{3}$ factorial experiments and three central points, together with the six additional star points, were performed. The experiments were performed in randomized order (to minimize the effects of the uncontrolled factors) with three replications at the design center to obtain an accurate estimation of the experimental error. The complete design matrix of the applied experiments is showed later.

An empirical model correlating FAME yield to the three parameters was developed. Analysis of variance (ANOVA) was applied to evaluate the fitness of the model and identify the interactions between the variables and the responses thought statistical significance test by $F$ value and $P$ value. The goodness of fit of the polynomial model was expressed by the coefficients of determination, $R^{2}$, which indicated the quality of the fit of polynomial.

\section{Results and Discussion}

The elemental chemical composition (Table 1), determined with X-ray fluorescence spectroscopy, indicated that the natural dolomite is composed mainly of calcium and magnesium with a small amount of impurity, in which silicon was the most significant component.

On the other hand, the presence of silicon oxide will not promote a change in the catalytic behaviour because $\mathrm{SiO}_{2}$ is known to be a neutral support for catalytic process [25]. 
TABLE 1: Elemental chemical composition (atom) of the naturally occurring dolomite determined by using X-ray fluorescence spectroscopy.

\begin{tabular}{lc}
\hline Element & Percentage (wt\%) \\
\hline $\mathrm{Ca}$ & 77.0 \\
$\mathrm{Mg}$ & 17.7 \\
$\mathrm{Si}$ & 4.6 \\
Other components $(\mathrm{Fe}, \mathrm{Al}, \mathrm{K})$ & 0.7
\end{tabular}

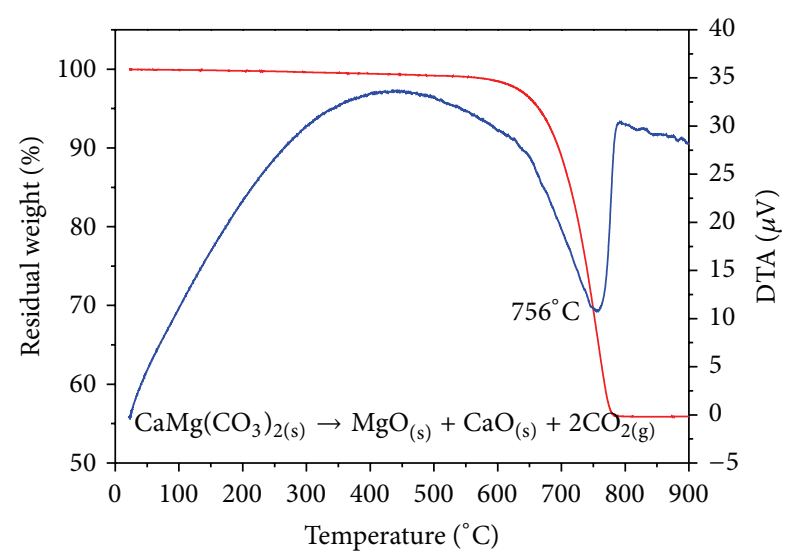

FIgURE 1: Thermogravimetric analysis and differential thermal analysis (TGA/DTA) curves for noncalcined dolomite.

Therefore, due to the basic properties of $\mathrm{CaO}$ and the high $\mathrm{Ca}$ percentage observed, it suggests that the material may present a good catalytic performance.

The thermal behaviour of natural dolomite was studied by TGA/DTA and experimental curves for the same are presented in Figure 1. Only one endothermic weight loss at $756^{\circ} \mathrm{C}$ was observed in TGA/DTA curve of the dolomite before the calcination. The weight loss, which corresponds to a total of $42.9 \%$, starts from $570^{\circ} \mathrm{C}$ and is complete at $785^{\circ} \mathrm{C}$.

This endothermic event is related to the thermal decomposition process of dolomite $\left(\mathrm{CaMg}\left(\mathrm{CO}_{3}\right)_{2}\right)$, leading to the formation of $\mathrm{MgO}$ and $\mathrm{CaO}$. Therefore, the TG profile suggests that the calcination temperature required for complete decomposition of the carbonates groups should be higher than $700^{\circ} \mathrm{C}$. To support the results as seen by TGA/DTA curve, XRD studies were taken on dolomite, before the calcinations, and for the powder obtained by its calcination at $700^{\circ} \mathrm{C}$ and $800^{\circ} \mathrm{C}$, to confirm the $\mathrm{CaO}$ and $\mathrm{MgO}$ phase formation.

The XRD profile of natural dolomite and dolomite calcined at 700 and $800^{\circ} \mathrm{C}$ are shown in Figure 2. It can be seen clearly that in the natural dolomite a mixture of $\mathrm{CaMg}\left(\mathrm{CO}_{3}\right)_{2}$, $\mathrm{CaCO}_{3}$ and $\mathrm{SiO}_{2}$ phases are present; however, dolomite is the main phase (Figure 2(a)). This result was confirmed by Rietveld method [26] applied for the refinement of the diffraction profiles. Moreover, by the Rietveld method, it was possible to quantify the different phase in the sample (Table 2). These results agree with those of the XRF elemental composition analysis, which showed $\mathrm{Ca}$ and $\mathrm{Mg}$ with small amount of silicon as main chemical element.

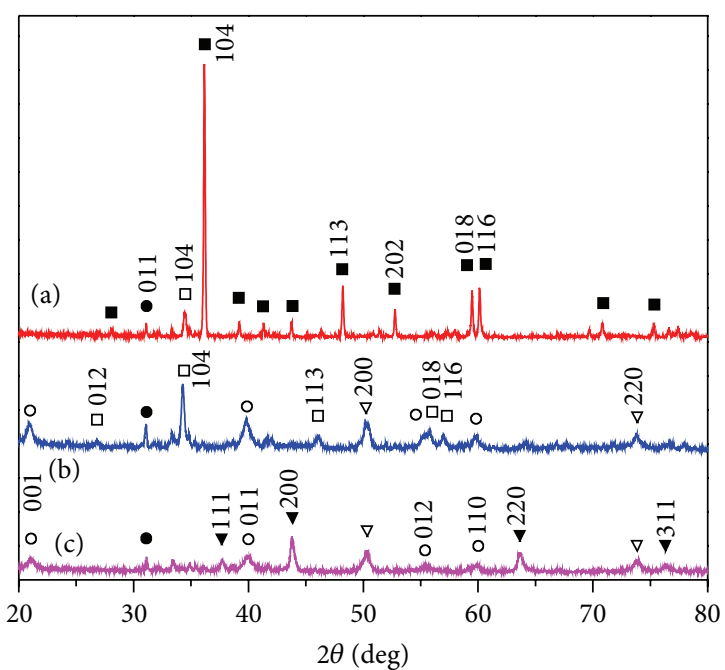

FIgURE 2: X-ray diffraction (XRD) of noncalcined dolomite (a), calcined at $700(\mathrm{~b})$ and $800^{\circ} \mathrm{C}(\mathrm{c}) . \mathbf{a}-\mathrm{CaMg}\left(\mathrm{CO}_{3}\right)_{2} ; \square-\mathrm{CaCO}_{3} ; \bullet-$ $\mathrm{SiO}_{2} ; \mathrm{O}-\mathrm{Ca}(\mathrm{OH})_{2} ; \boldsymbol{\nabla}-\mathrm{CaO} ; \nabla-\mathrm{MgO}$.

Figure 2(a) shows a more complex diffraction profile with primary $2 \theta$-diffraction peaks $(28.0,36.1,39.1,41.1,44.0$, $48.6,52.7,59.7$, and 60.1$)$ that correspond to dolomite phase $\left(\mathrm{CaMg}\left(\mathrm{CO}_{3}\right)_{2}\right)$, with rhombohedral structure and R-3 space group (JCPDS file 01-079-1342). In addition, diffraction peak of $\mathrm{SiO}_{2}$ phase ( $2 \theta$ at 31.1 ), with hexagonal structure and $\mathrm{P} 3121$ space group (JCPDS file 01-086-1628), and $\mathrm{CaCO}_{3}$ phase $(2 \theta$ at 34.4 and 56.1), with rhombohedral structure and R-3c space group (JCPDS file 01-072-1650), were detected in the raw dolomite material. The results in Figure 2(a) lead to the conclusion that the solid is a natural dolomite that contains $\mathrm{Ca}$ and $\mathrm{Mg}$ with a small amount of calcite and silicon oxide.

The reflections intensity arising from dolomite (Figure 2) is reduced significantly for the samples calcined at $700^{\circ} \mathrm{C}$ and $800^{\circ} \mathrm{C}$, which is coincident with the appearance of new crystalline phases (Figures 2(b) and 2(c)). Therefore, it is not possible to confirm the presence of dolomite phase after the calcinations process, differently from what was observed by Niu et al. [20], which detected the presence of dolomite after calcination at $700^{\circ} \mathrm{C}$.

The sample calcined at $700^{\circ} \mathrm{C}$ showed intense diffraction peaks ( $2 \theta$ of 50.3 and 73.7 ) related to a cubic structure of $\mathrm{MgO}$ phase, with Fm-3m space group (JCPDS file 01-0750447). In addition, characteristics and intense $2 \theta$-diffraction peaks $\left(26.8,34.3,46.2,55.8\right.$, and 56.9) related to $\mathrm{CaCO}_{3}$ (calcite, JCPDS file 01-072-1650) and a hexagonal structure of $\mathrm{Ca}(\mathrm{OH})_{2}$ phase $(2 \theta$ of $21.0,39.9,55.2,59.9$, and 64.2$)$, with P-3ml space group (JCPDS file 01-084-1263), were also observed. The presence of $\mathrm{Ca}(\mathrm{OH})_{2}$ may be explained by the air exposure of the formed sample, which resulted from water adsorption; likewise, the adsorption of carbon dioxide on $\mathrm{CaO}$ may form $\mathrm{CaCO}_{3}$ [17]. Therefore, the presence of $\mathrm{Ca}(\mathrm{OH})_{2}$ phase suggests that a certain percentage of $\mathrm{CaO}$ also is formed at $700^{\circ} \mathrm{C}$, which, due to air humidity exposure can result in the formation of $\mathrm{Ca}(\mathrm{OH})_{2}$. It happened because the sample was not subjected to XRD procedure immediately 
TABLE 2: Structural properties of the dolomite catalyst determined by XRD.

\begin{tabular}{|c|c|c|c|}
\hline \multirow{2}{*}{ Samples } & \multicolumn{3}{|c|}{ Structural } \\
\hline & Phase detected & Crystalline phase $\mathrm{e}^{\mathrm{a}}$ & Crystallite diameter $(\mathrm{nm})^{\mathrm{b}}$ \\
\hline \multirow{3}{*}{ Dolomite } & $\mathrm{CaMg}\left(\mathrm{CO}_{3}\right)_{2}$ & 92.05 & 96.0 \\
\hline & $\mathrm{Ca}\left(\mathrm{CO}_{3}\right)$ & 6.72 & 22.0 \\
\hline & $\mathrm{SiO}_{2}$ & 1.22 & 99.4 \\
\hline \multirow{4}{*}{$\mathrm{D}-700^{\circ} \mathrm{C}$} & $\mathrm{MgO}$ & 31.52 & 17.5 \\
\hline & $\mathrm{Ca}(\mathrm{OH})_{2}$ & 38.75 & 12.9 \\
\hline & $\mathrm{Ca}\left(\mathrm{CO}_{3}\right)$ & 27.56 & 28.9 \\
\hline & $\mathrm{SiO}_{2}$ & 2.17 & 125.4 \\
\hline \multirow{4}{*}{$\mathrm{D}-800^{\circ} \mathrm{C}$} & $\mathrm{CaO}$ & 23.57 & 23.8 \\
\hline & $\mathrm{MgO}$ & 33.57 & 17.7 \\
\hline & $\mathrm{Ca}(\mathrm{OH})_{2}$ & 40.41 & 12.6 \\
\hline & $\mathrm{SiO}_{2}$ & 2.45 & 129.1 \\
\hline
\end{tabular}

${ }^{\mathrm{a}}$ After Rietveld refinement (wt\%) [26], ${ }^{\mathrm{b}}$ Scherrer equation.

after the calcinations process, consequently the sample was exposed to the atmospheric air.

After thermal decomposition at $800^{\circ} \mathrm{C}$ (Figure 2(c)), it is observed diffraction peaks at $2 \theta$ of $37.7,43.7$ and 63.7, which are related to $\mathrm{CaO}$ phase (cubic structure with $\mathrm{Fm}-3 \mathrm{~m}$ space group, JCPDS file 01-078-0649). CaO simultaneously with $\mathrm{MgO}(2 \theta$ of 50.3 and 73.7$)$ and $\mathrm{Ca}(\mathrm{OH})_{2}(2 \theta$ of $21.0,33.4,39.9$, 55.6 , and 59.9) are the main phases formed, and no diffraction peak of $\mathrm{CaCO}_{3}$ phase was detected. Therefore, the calcination process at $800^{\circ} \mathrm{C}$ is sufficient to give a higher amount of $\mathrm{MgO}$ and $\mathrm{CaO}$ phases, which are basic metal oxides active in the transesterification reaction.

These results agree well with the TG results (Figure 1) and indicate that, at $800^{\circ} \mathrm{C}$, the thermal decomposition reaction of dolomite is completed. Therefore, based on this finding, the dolomite was activated at $800^{\circ} \mathrm{C}$ for the reaction process and further characterizations.

Applying the Scherrer equation (1) for all diffraction peaks, after Rietveld refinement, for each phase, it was possible to estimate the mean crystallite diameter for the phases confirmed (Table 2). As can be seen in Table 2 the $\mathrm{CaMg}\left(\mathrm{CO}_{3}\right)_{2}$ phase has the average crystallite size of $96 \mathrm{~nm}$, corresponding to $92.05 \mathrm{wt} \%$ of the crystalline phase. In addition to the dolomite phase decomposition, the effect of the heat treatment at $700^{\circ} \mathrm{C}$ is also observed over the $\mathrm{CaCO}_{3}$ phase, which point to a noticeable increasing on the wt $\%$ of the phase (6.72 to $27.56 \mathrm{wt} \%)$ :

$$
D=\frac{k \cdot \lambda}{\beta \cdot \cos \theta},
$$

where $D$ is the crystallite diameter; $k$ is a crystallographic constant; $\lambda$ is the irradiation wavelength applied in the XRD; $\beta$ is the half width; $\theta$ is the diffraction angle.

Increasing the calcinations temperature to $800^{\circ} \mathrm{C}$ has no effect over the wt\% and the crystallite diameter of the $\mathrm{MgO}$ and $\mathrm{Ca}(\mathrm{OH})_{2}$ phases, while the $\mathrm{CaCO}_{3}$ is lost. The lower average crystallite size observed for the $\mathrm{CaO}$ and $\mathrm{MgO}$ phases pointed to a low effect in the sintering process at $800^{\circ} \mathrm{C}$ (Table 2). The $\mathrm{SiO}_{2}$ phase, however, shows an enlargement of

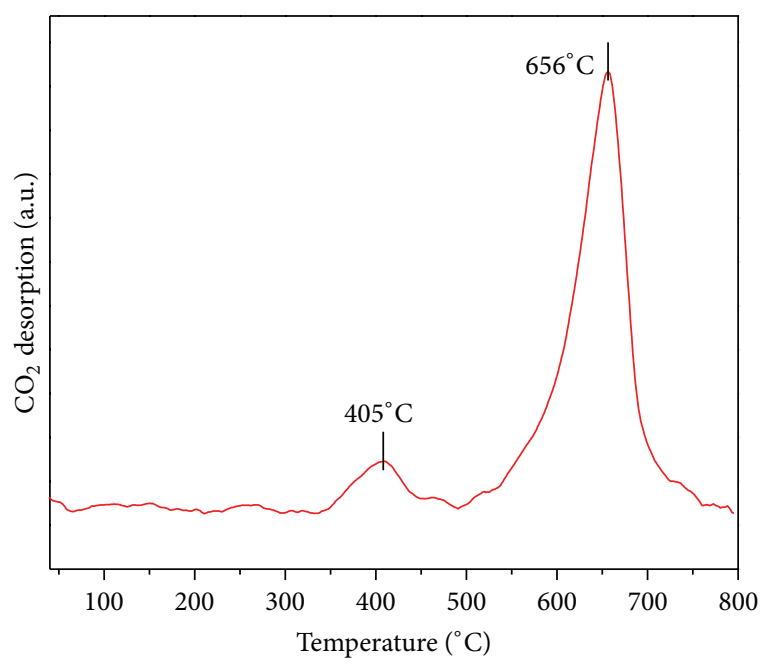

FIgURE 3: TPD- $\mathrm{CO}_{2}$ curves obtained under flowing $\mathrm{He}$ for the naturally occurring dolomite calcined at $800^{\circ} \mathrm{C}$.

the average crystallite size due to the increase of the calcination temperature.

To gather information about the basicity of the dolomite sample after calcination at $800^{\circ} \mathrm{C}$, the TPD- $\mathrm{CO}_{2}$ analysis was performed. TPD- $\mathrm{CO}_{2}$ profiles (Figure 3 ) clearly revealed the presence of two basic sites with different strengths. The low-temperature peak, with a maximum desorption near $400^{\circ} \mathrm{C}$, may be attributed to the interaction of $\mathrm{CO}_{2}$ with sites of medium basic strength. According to [7, 17], these sites are mainly associated with the oxygen in the $\mathrm{Mg}^{2+}$ $\mathrm{O}^{2-}$ pairs. The high-temperature peak, with a maximum at approximately $650^{\circ} \mathrm{C}$, is associated with $\mathrm{CO}_{2}$ desorption from sites with strong basicity, which correspond to $\mathrm{CaO}$. Similar value was reported by Shajaratun Nur et al. [18].

The maximum of $656^{\circ} \mathrm{C}$ is lower than those observed by Yoosuk et al. [17]. However, such difference may be due to the experimental procedure. In this work the sample was preheated at $800^{\circ} \mathrm{C}$. This ensures that the existing $\mathrm{CaCO}_{3}$ is decomposed before the TPD run. 


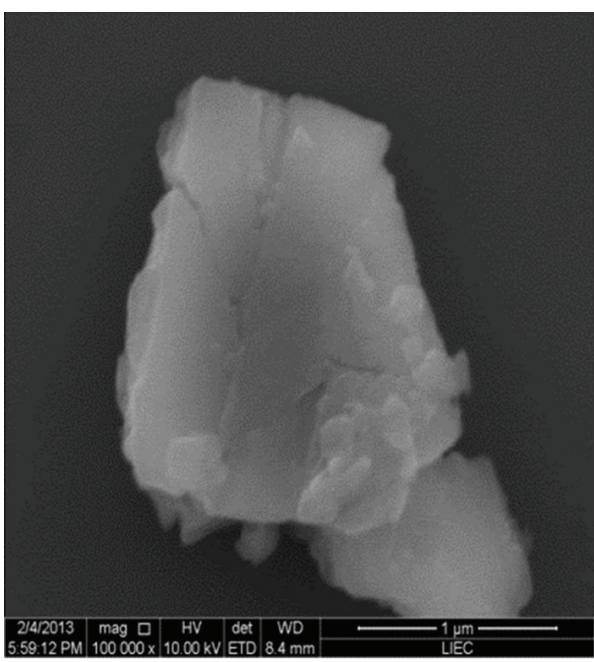

(a)

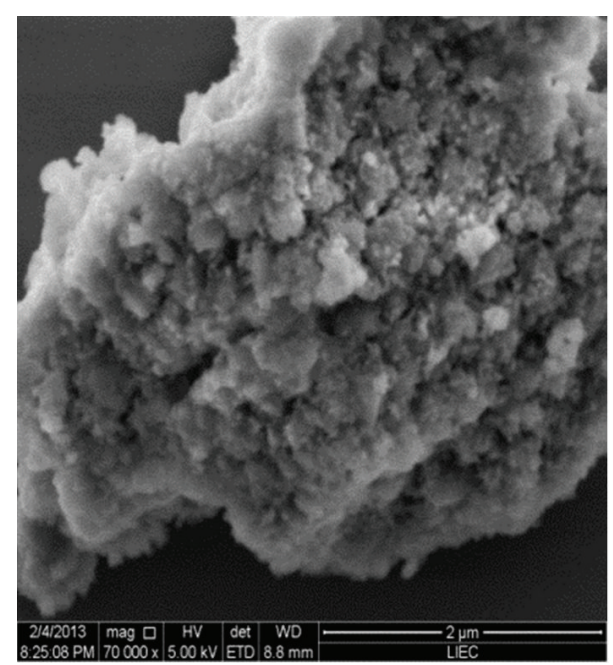

(b)

FIGURE 4: SEM micrographs for natural dolomite (a) and calcined at $800^{\circ} \mathrm{C}$ (b).

Therefore, although the TG analysis (Figure 1) shows the inflexion point at $725^{\circ} \mathrm{C}$ for the $\mathrm{CaCO}_{3}$ decomposition, one should keep in mind that for the TPD- $\mathrm{CO}_{2}$ analysis what is observed is the $\mathrm{CO}_{2}$ adsorbed on the outer surface of the oxide, and not in the bulk of the sample. In other words, a lower amount of $\mathrm{CO}_{2}$ is eliminated from the sample. Consequently it seems to present a shift to lower temperature [17].

Assuming that $\mathrm{CO}_{2}$ from $\mathrm{MgO}$ should desorb at lower temperatures compared to the $\mathrm{CO}_{2}$ from $\mathrm{CaO}$ [27], the profile in Figure 3 shows that $\mathrm{CO}_{2}$ is mainly adsorbed on $\mathrm{CaO}$. Based on the information collected by the TPD technique, the coexistence of two different basic oxide components in a solid can be advantageous for transesterification. Apparently, the presence of $\mathrm{Mg}$ in the sample does not promote any prejudicial influence on the basic properties of $\mathrm{CaO}$; the maximum in the $\mathrm{CO}_{2}$ desorption peak at $656^{\circ} \mathrm{C}$ points to a strongly basic site and corroborate with the TPD- $\mathrm{CO}_{2}$ results previously reported for $\mathrm{CaO}$ by Constantinou et al. [27].

The specific surface area was obtaining by the $\mathrm{N}_{2}$ adsorption/desorption isotherm. The sample exhibited a type-II isotherm (not shown), with almost no hysteresis loop. These features are typical of nonporous or macroporous materials. The values of the surface area and pore volume are $14 \mathrm{~m}^{2} / \mathrm{g}$ and $0.015 \mathrm{cc} / \mathrm{g}$, respectively. This result suggests that the complete decarbonation of $\mathrm{CO}_{2}$, along with the sintering effect, results in a material with low value for the textural properties. Therefore, these values suggest that the active site access will not present a diffusion problem because the active site is present at the external surface, which may result in a faster interaction between the material and the alcohol present in the reaction mixture.

The surface morphology of natural and calcined dolomite was also examined by SEM (Figures 4(a) and 4(b)). The natural dolomite shows comprised large particles, exposing smooth planes with surface relatively homogeneous. The calcination process generates fractures on these particles, as

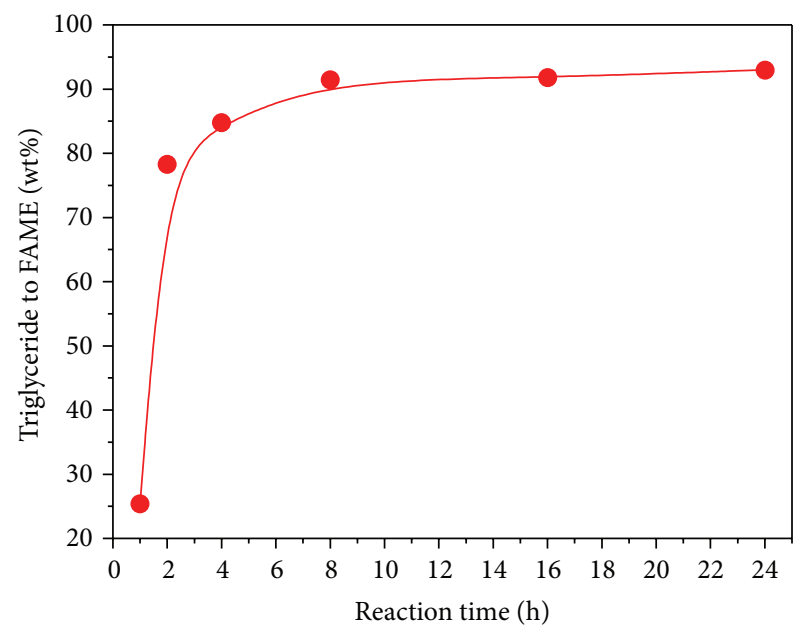

FIGURE 5: Effect of reaction time on the FAME production. Reaction conditions: catalyst amount of $0.6 \mathrm{wt} \%$; methanol/oil ratio of 6 ; temperature of $55^{\circ} \mathrm{C}$.

expected from the decomposition of the carbonate groups, liberating $\mathrm{CO}_{2}$ with the formation of $\mathrm{CaO}$ and $\mathrm{MgO}$ phases, which have small surface area.

Considering the results presented so far, $800^{\circ} \mathrm{C}$ was the temperature fixed for the calcination process. Therefore the independent variables chosen for the catalytic test were reaction temperature $(T)$, methanol/oil ratio $(R)$, and amount of catalyst $(C)$; the reaction time was fixed in $4 \mathrm{~h}$. This time was chosen after reviewing the results present in Figure 5, which shows that after $4 \mathrm{~h}$ of reaction time, the methyl-ester production is $85 \%$, and the maximum (93\%) were reached after $8 \mathrm{~h}$.

The increase of the methyl-ester production from $85 \mathrm{wt} \%$ to $93 \mathrm{wt} \%$ is not so expressive in order to keep the reaction system plus $4 \mathrm{~h}$ (total of $8 \mathrm{~h}$ ). In addition, the reaction condition for the results presented in Figure 5 is the less 
TABLE 3: Central composite design arrangement and results for transesterification of soybean oil using dolomite calcined at $800^{\circ} \mathrm{C}$ and a reaction time of $4 \mathrm{~h}$.

\begin{tabular}{lcccc}
\hline \multirow{2}{*}{ Run } & \multicolumn{3}{c}{ Independent variables } & \multirow{2}{*}{ FAME yield (wt\%) } \\
& $T\left({ }^{\circ} \mathrm{C}\right)$ & $R$ & $C(\mathrm{wt} \%)$ & 85.5 \\
1 & 55 & 6 & 0.6 & 89.9 \\
2 & 65 & 6 & 0.6 & 93.6 \\
3 & 55 & 15 & 0.6 & 96.1 \\
4 & 65 & 15 & 0.6 & 92.6 \\
5 & 55 & 6 & 2.0 & 91.6 \\
6 & 65 & 6 & 2.0 & 93.2 \\
7 & 55 & 15 & 2.0 & 94.3 \\
8 & 65 & 15 & 2.0 & 93.7 \\
9 & 60 & 10.5 & 0.6 & 95.0 \\
10 & 60 & 10.5 & 2.0 & 94.4 \\
11 & 60 & 15 & 1.3 & 89.3 \\
12 & 60 & 6 & 1.3 & 94.6 \\
13 & 65 & 10.5 & 1.3 & 95.6 \\
14 & 55 & 10.5 & 1.3 & 97.3 \\
15 & 60 & 10.5 & 1.3 & 96.5 \\
16 & 60 & 10.5 & 1.3 & 97.1 \\
17 & 60 & 10.5 & 1.3 & \\
\hline
\end{tabular}

favourable between those chosen and presented in Table 3 . That is to say, the temperature of $55^{\circ} \mathrm{C}$, methanol/oil ratio of 6 , and catalyst amount of $0.6 \mathrm{wt} \%$ are the lower values for the variables and will probably present the lower methyl-ester production.

Therefore, by fixing the calcination temperature at $800^{\circ} \mathrm{C}$ and the reaction time in $4 \mathrm{~h}, 17$ catalytic tests were carried out, whose conditions and methyl-ester (FAME) production are presented in Table 3. It is important to point out the triplicate for the centred point.

The experimental results shown in Table 3 were submitted to a multiple regression analysis and were fitted to the polynomial equation. The regression equation as a function of the selected variables for FAME yield (\%) is given by

$$
\begin{aligned}
\text { FAME yield }(\%)= & 37.45+0.42 T+4.37 R-0.16 R^{2} \\
& +24.26 C-1.53 C^{2}+0.001 \mathrm{TR} \\
& -0.24 \mathrm{TC}-0.44 \mathrm{RC},
\end{aligned}
$$

where $T$ is the reaction temperature, $R$ is the methanol/oil ratio, and $C$ is the catalyst weight.

Statistical analysis of variance (ANOVA) was used to evaluate the adequacy of the fitted model studying the significance of the individual terms and their interactions on the FAME yield (Table 4). In ANOVA analysis, information from all the experiments is used in the analysis of the results, making ANOVA a more powerful tool than varying only one factor at a time. The coefficient of determination $\left(R^{2}\right)$ and the parameters $F$ value ( $F$ test) and $P$ value were used to judge the adequacy of the model [27].

According to the ANOVA results (Table 4), for the term to be considered statistically significant the calculated $F$ value

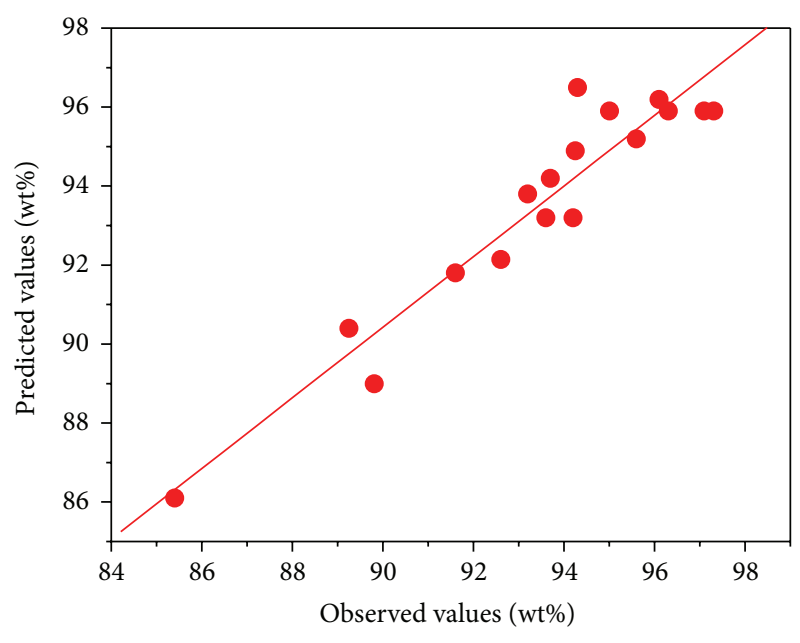

FIGURE 6: Experimental versus predicted values of FAME yield.

should be greater than the tabulated $F$ value ( $F$ test with 95\% confidence level) and the $P$ values should be less than 0.05 (probability of error value). The calculated $F$ value is defined as the ratio between the mean of the square regression and the mean of the square residual error.

From Table 4 it is clear that the linear terms for methanol/oil ratio $(R)$ and catalyst amount $(C)$ have large effects on FAME yield due to high $F$ values and low $P$ values. In addition, the linear term for temperature $(T)$ is also significant but with a smaller effect on the FAME yield due to its smaller $F$ value than the other linear terms. However, the quadratic term for methanol/oil ratio $\left(R^{2}\right)$ has a large $F$ value and a lesser $P$ value. Thus, the effect of methanol/oil ratio on the FAME yield is most strongly modelled with the quadratic term. The quadratic term for the temperature $\left(T^{2}\right)$ and catalyst amount $(C)$ were insignificant comparing their corresponding linear terms. The coupling terms between temperature-catalyst amount (TC) and the molar ratiocatalyst amount (RC) were significant indicating a higher interaction between those two variables. The accuracy and variability of the above model could be evaluated by the coefficient of determination. The coefficient of determination $\left(R^{2}\right)$ of the model obtained is 0.9130 , which indicates that $91.30 \%$ of the variability in the dependent variable could be explained.

A comparison of the experimental results with the model values of FAME yield predicted from the above equation is depicted in Figure 6. As can be seen, the experimental values were distributed relatively near to a straight line and a satisfactory correlation between these values is observed. This plot, therefore, provides visual confirmation that the regression model equation provided a good description of the experimental data with the model.

The response surface plot (Figure 7) can illustrate very well the effect of the three studied operating conditions and their interactions on FAME yield. Figure 7(a) shows that the maximum FAME yield was achieved when the ratio of methanol to oil and catalyst amount are increased to approximately their mid-range because these factors have 
TABLE 4: Statistical analysis of variance (ANOVA) for the regression model terms in the production of methyl esters; $F_{\text {tab. }}=8.73$.

\begin{tabular}{|c|c|c|c|c|}
\hline Model term & Sum of squares & Mean of squares & $F$ value & $P$ value \\
\hline$T$ & 3.600 & 3.600 & 20.769 & 0.0449 \\
\hline$T^{2}$ & 0.00 & 0.00 & 0.000 & 1.0000 \\
\hline$R$ & 51.529 & 51.529 & 297.282 & 0.0033 \\
\hline$R^{2}$ & 28.299 & 28.299 & 163.266 & 0.0060 \\
\hline C & 6.241 & 6.241 & 36.005 & 0.0266 \\
\hline$C^{2}$ & 1.507 & 1.507 & 8.694 & 0.0983 \\
\hline TL by RL & 0.005 & 0.005 & 0.028 & 0.880 \\
\hline TL by CL & 5.780 & 5.780 & 33.346 & 0.028 \\
\hline RL by CL & 15.125 & 15.125 & 87.2596 & 0.0112 \\
\hline Pure error & 0.3467 & 0.17333 & & \\
\hline $\begin{array}{l}R \text {-squared } \\
0.9130\end{array}$ & & & & \\
\hline
\end{tabular}

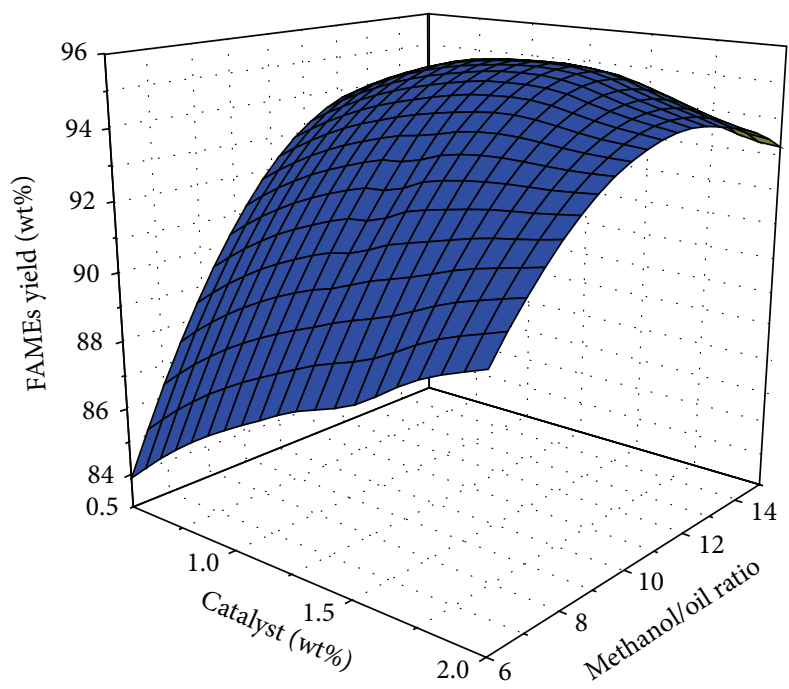

(a)

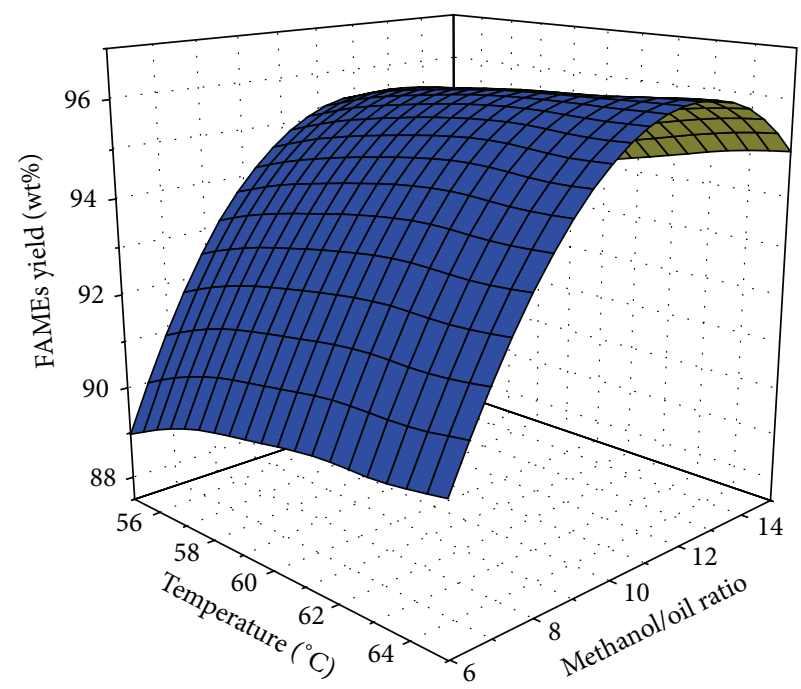

(b)

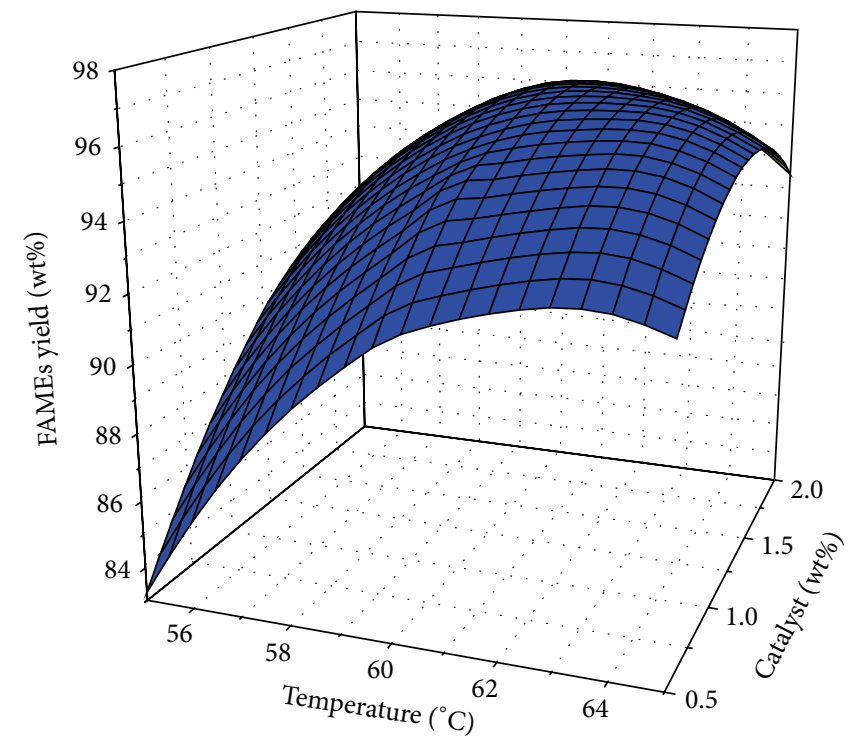

(c)

FIGURE 7: Response surface plot of FAME yield, as a function of the catalyst amount and the molar ratio (a), the molar ratio and the reaction temperature (b), and the catalyst amount and the reaction temperature (c). 


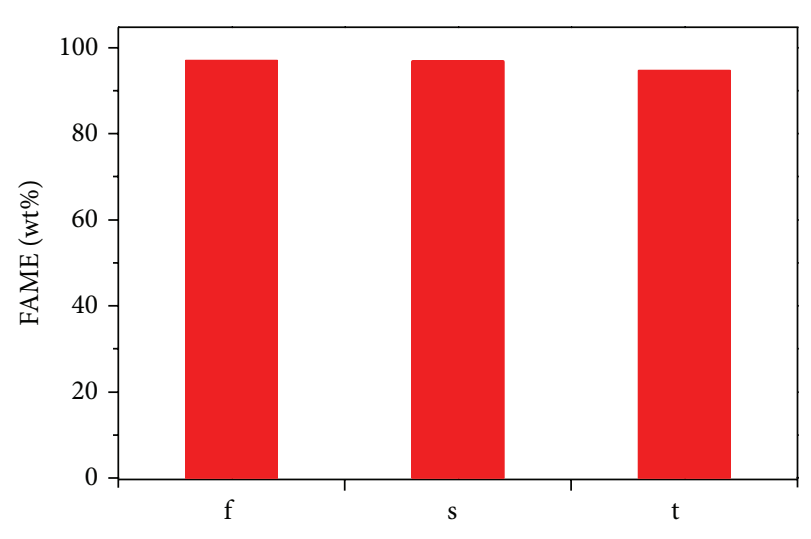

(a)

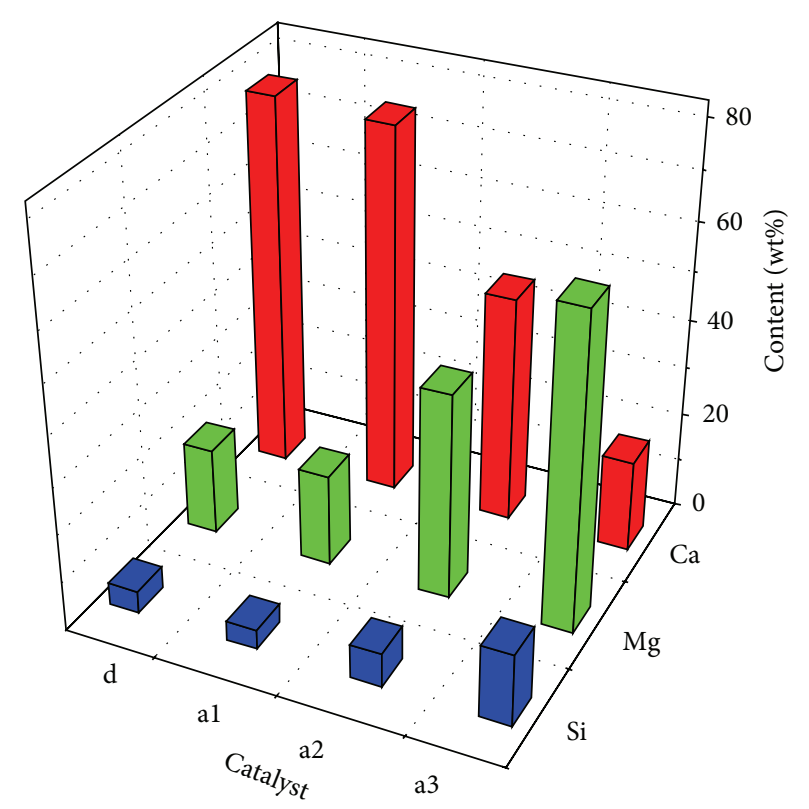

(b)

FIGURE 8: (a) FAMEs yield for the first test (f), for the second test ( $\mathrm{s}$ ), and for the third test (t). (b) Catalyst composition change due to the successive catalytic test. $\mathrm{d}=$ dolomite, $\mathrm{a} 1=$ after first using, $\mathrm{a} 2=$ after first reusing, and a $3=$ after second reusing.

positive effects on the response (2). However, an increase in the values of the variables beyond a certain amount of mid-range leads to a slight reduction in FAME yield. This decrease is observed in (1), since the quadratic term has negative sign. Therefore, as observed by Constantinou et al. [27], the reaction rate increase for triglyceride conversion to FAME was obtained because of the increment in the number of active sites; the excess of catalyst, however, can disturb the oil-methanol-catalyst mixture and cause a phase separation that, for diffusion reasons, inhibits the reaction.

Since the transesterification reaction is reversible in nature, an increase in the amount of methanol in the reaction mixture shifts the equilibrium to the right-hand side, with more methyl-ester formation. On the other hand, performing the reaction at high ratios of methanol/oil promotes difficulties in the separation of the methyl-ester and glycerol layers [16]. Thus, monoglycerides and diglycerides can homogenise the phases of methanol, glycerol, and methyl-ester, which favours the reverse reaction and decreases the FAME yield. However, as may be a high FAME content in the glycerine rich phase, the FAME rich phase may have a high content of glycerine. Therefore, this phenomenon provides the determination of FAME content lower than expected [16].

Figures 7(b) and 7(c) show the influence of the interactive factor of methanol/oil ratio and catalyst amount as a function of temperature. It can be seen that an increase in the values of each parameter-temperature, molar ratio, and catalyst amount - to approximately the middle of the corresponding investigated range, achieves the maximal amount of FAME yield (see Figures $7(\mathrm{~b})$ and $7(\mathrm{c})$ ). This shows that the transesterification reaction can be favoured when adequate temperatures are used $[12,28]$.
According to Figures 7(b) and 7(c), the FAME yield was highest at a temperature of $60^{\circ} \mathrm{C}$ and when the molar ratio and catalyst amount were increased to values at approximately their mid-range. The transesterification reaction rate increases as the temperature increases; this result is expected because of the temperature dependence of the reaction kinetics. However, the operation temperature cannot reach the boiling point of the mixture due to methanol evaporation. The evaporation of methanol results in the formation of bubbles, which inhibit the interaction between the reactants and the catalyst interface.

The coupling terms between temperature and molar ratio (Figure $7(\mathrm{~b})$ ) show a low effect due to the temperature increase; this behaviour is perceived in (1).

Applying the response surface design for the results presented here, it was observed that the optimum values for the variables of the process to reach a maximum in methyl-ester production were obtained when central point conditions were used, that is, a reaction temperature of $60^{\circ} \mathrm{C}$, a methanol/oil ratio of 10.5 , and $1.3 \mathrm{wt} \%$ of catalyst. Under such conditions, a FAME yield of $97.0 \%$ was reached. This conversion percentage is within the limits established by the European Union Standard EN 14214, which stipulate that the ester content should be greater than or equal to $96.5 \mathrm{wt} \%$.

Although it is possible to carry out an additional transesterification reaction, in order to improve the FAME content in the biodiesel produced, at this point it is interesting to make a comparison of the results presented in the literature. Table 5 summarizes such comparison considering the temperature, methanol/oil ratio, reaction time, and catalyst amount. Because the number of papers related to the $\mathrm{CaO}$ performance in the transesterification of vegetable oil to 
TABLE 5: Higher FAME yield reached with dolomite as a heterogeneous catalyst for the methanol/oil transesterification reaction.

\begin{tabular}{lccccc}
\hline$T\left({ }^{\circ} \mathrm{C}\right)$ & $R$ & $C(\mathrm{wt} \%)$ & $t(\mathrm{~min})$ & FAME $(\mathrm{wt} \%)$ & Reference \\
\hline 60 & 10.5 & 1.3 & 240 & 97.0 & 94.3 \\
60 & 10 & 3 & 180 & 98.0 & This work \\
65 & 20 & 1 & 360 & 91.8 & {$[17]$} \\
67.5 & 6 & 3 & 180 & 98.6 & {$[18]$} \\
60 & 30 & 6 & 180 & 97.9 & {$[11]$} \\
64 & 12 & 4 & 180 & 96.1 & {$[19]$} \\
60 & 50 & 10 & 180 & {$[16]$} \\
\hline
\end{tabular}

$T=$ reaction temperature, $R=$ methanol/oil ratio, $C=$ catalyst amount, and $t=$ reaction time.

produce biodiesel is considerable [29], the data from Table 5 are for the natural dolomite application only.

In general the results presented in Table 5 show a high FAME yield for the first transesterification process. Jaiyen et al. [19] showed the higher FAME yield (98.6 wt $\%$ ) at $60^{\circ} \mathrm{C}$ and $180 \mathrm{~min}$ of reaction time. However, this result is achieved with a methanol/oil ratio of 30 , in addition to the high catalyst content (6 wt\%). Similar FAME yield (98 wt\%) was achieved by Shajaratun Nur et al. [18] with a catalyst content of $1 \mathrm{wt} \%$. However this conversion is reached after $360 \mathrm{~min}$ of reaction time and a methanol/oil ratio of 20 at $65^{\circ} \mathrm{C}$. Niu et al. [20] showed a FAME yield of $97.9 \mathrm{wt} \%$ with 1890 min of reaction time, but using $4 \mathrm{wt} \%$ of catalyst content.

An interesting result for the FAME yield is presented by Ilgen [11], $91.8 \mathrm{wt} \%$ (FAME) with $180 \mathrm{~min}$ of reaction time and a methanol/oil ratio of 6 . However, the temperature and the catalyst amount also are high.

Although the FAME yields from the present work were achieved with $240 \mathrm{~min}$ of reaction time, it is important to point out the similar result presented by Yoosuk et al. [17] (Table 5). Despite (2) being valid in the catalyst amount range of 0.6 to $2.0 \mathrm{wt} \%$, applying in (2) the reaction condition from Yoosuk et al. [17] (Table 5), the FAME yield calculated is $93.56 \mathrm{wt} \%$, which is similar to the result presented by Yoosuk et al. (94.3 wt\%).

Therefore, the results presented here show the importance of statistical approach to determine the best reaction conditions.

From the economical point of view the catalyst recycling is very important. Therefore, reusability tests were also carried out in the same reaction conditions cited above $(T=$ $60^{\circ} \mathrm{C}, R=10.5$, and $C=1.3$ ). Before each reuse process the catalyst was regenerated by calcinations at $800^{\circ} \mathrm{C}$.

Figure 8(a) shows the FAME yield after two-reuse process. The FAME yield for the first reuse is practically the same of the fresh catalyst; however, in the second reuse the FAME yield falls to $95 \%$. This is a high methyl-ester content; but a third or fourth reuse process will present lowest content of FAME.

As previously mentioned, the catalyst was always reactivated before each reuse. So, it would not be expected catalytic deactivation due to residual organic substances deposited on the sample surface.

Therefore, it is necessary and interesting to analyze the catalyst composition after each test. The elemental analysis results are shown in Figure 8(b). Practically there is no catalytic composition change after the first using; however, after the first and the second reuse process the catalyst composition change significantly. These results point to a leaching of the main active specie from the catalyst solid sample. Thus, as the calcium oxide is the main active site, the decrease in calcium content results in the methyl-ester production decrease.

As showed in previous papers [30-32], both $\mathrm{MgO}$ and $\mathrm{CaO}$ are active in the transesterification reaction. However, it is known that $\mathrm{CaO}$ is more active than $\mathrm{MgO}[33,34]$. Therefore, despite the significant decrease in calcium content (Figure $8(\mathrm{~b})$ ), the decrease in the FAME wt\% production is not considerable (from 97 to $95 \mathrm{wt} \%$ ) because of the $\mathrm{MgO}$ content.

The leaching is prejudicial to the catalytic process; thus, these results may suggest that dolomite is not applicable for transesterification process. On the other hand, if it is considered the low cost of obtaining the dolomite, three cycles of use can be significant. In addition, the calcium content in the biodiesel, due to the leaching process, can be removed efficiently by using a sulfonic resin [35].

\section{Conclusions}

The calcined dolomite was found to be an effective basic catalyst in the transesterification of triglycerides for biodiesel production. Using the response surface methodology, a suitable method to study the effect of three operating variables, it is shown that within the experimental range considered, the most important factors were the molar ratio and the amount of catalyst. In spite of the calcium to be the main leached component, which limits the reuse process to a few times, the dolomite application in the FAME production is favourable from an economic and environmental point of view.

\section{Conflict of Interests}

The authors declare that there is no conflict of interests regarding the publication of this paper.

\section{Acknowledgments}

The authors acknowledge Dr. J. M. Sasaki (Lab. de Raios XUFC) for the DRX and FRX analysis, Dr. E. R. Leite, and A. N. 
Pinheiro (LIEC-UFSCar) for the SEM analysis and ITAMIL (Itaóca Mineration) for the donation of the dolomite, and the Brazilian research-funding support agency, CNPq.

\section{References}

[1] A. E. Atabani, A. S. Silitonga, H. C. Ong et al., "Non-edible vegetable oils: a critical evaluation of oil extraction, fatty acid compositions, biodiesel production, characteristics, engine performance and emissions production," Renewable and Sustainable Energy Reviews, vol. 18, pp. 211-245, 2013.

[2] G. F. Silva, F. L. Camargo, and A. L. O. Ferreira, "Application of response surface methodology for optimization of biodiesel production by transesterification of soybean oil with ethanol," Fuel Processing Technology, vol. 92, no. 3, pp. 407-413, 2011.

[3] S. Sinha, A. K. Agarwal, and S. Garg, "Biodiesel development from rice bran oil: transesterification process optimization and fuel characterization," Energy Conversion and Management, vol. 49, no. 5, pp. 1248-1257, 2008.

[4] B. Freedman, E. H. Pryde, and T. L. Mounts, "Variables affecting the yields of fatty esters from transesterified vegetable oils," Journal of the American Oil Chemists Society, vol. 61, no. 10, pp. 1638-1643, 1984.

[5] G. Vicente, M. Martínez, and J. Aracil, "Optimisation of integrated biodiesel production. Part II. A study of the material balance," Bioresource Technology, vol. 98, no. 9, pp. 1754-1761, 2007.

[6] M. E. Borges, L. Díaz, M. C. Alvarez-Galván, and A. Brito, "High performance heterogeneous catalyst for biodiesel production from vegetal and waste oil at low temperature," Applied Catalysis B: Environmental, vol. 102, no. 1-2, pp. 310-315, 2011.

[7] M. Di Serio, R. Tesser, L. Pengmei, and E. Santacesaria, "Heterogeneous catalysts for biodiesel production," Energy and Fuels, vol. 22, no. 1, pp. 207-217, 2008.

[8] P. C. Mazo and L. A. Rios, "Esterification and transesterification assisted by microwave of crude palm oil. Heterogeneous catalysis," Latin American Applied Research, vol. 40, no. 4, pp. 343-349, 2010.

[9] W. Roschat, M. Kacha, B. Yoosuk, T. Sudyoadsuk, and V. Promarak, "Biodiesel production based on heterogeneous process catalyzed by solid waste coral fragment," Fuel, vol. 98, pp. 194202, 2012.

[10] J. Warren, "Dolomite: occurence, evolution and economically important associations," Earth Science Reviews, vol. 52, no. 1-3, pp. 1-81, 2000.

[11] O. Ilgen, "Dolomite as a heterogeneous catalyst for transesterification of canola oil," Fuel Processing Technology, vol. 92, no. 3, pp. 452-455, 2011.

[12] C. Ngamcharussrivichai, P. Nunthasanti, S. Tanachai, and K. Bunyakiat, "Biodiesel production through transesterification over natural calciums," Fuel Processing Technology, vol. 91, no. 11, pp. 1409-1415, 2010.

[13] F. Qiu, Y. Li, D. Yang, X. Li, and P. Sun, "Heterogeneous solid base nanocatalyst: preparation, characterization and application in biodiesel production," Bioresource Technology, vol. 102, no. 5, pp. 4150-4156, 2011.

[14] W. M. Antunes, C. D. O. Veloso, and C. A. Henriques, "Transesterification of soybean oil with methanol catalyzed by basic solids," Catalysis Today, vol. 133-135, pp. 548-554, 2008.

[15] W. Xie, Y. Liu, and H. Chun, "Biodiesel preparation from soybean oil by using a heterogeneous $\mathrm{Ca}_{\mathrm{x}} \mathrm{Mg}_{2-\mathrm{x}} \mathrm{O}_{2}$ catalyst," Catalysis Letters, vol. 142, no. 3, pp. 352-359, 2012.
[16] C. Ngamcharussrivichai, W. Wiwatnimit, and S. Wangnoi, "Modified dolomites as catalysts for palm kernel oil transesterification," Journal of Molecular Catalysis A: Chemical, vol. 276, no. 1-2, pp. 24-33, 2007.

[17] B. Yoosuk, P. Udomsap, and B. Puttasawat, "Hydration-dehydration technique for property and activity improvement of calcined natural dolomite in heterogeneous biodiesel production: structural transformation aspect," Applied Catalysis A: General, vol. 395, no. 1-2, pp. 87-94, 2011.

[18] Z. A. Shajaratun Nur, Y. H. Taufiq-Yap, M. F. Rabiah Nizah, S. H. Teo, O. N. Syazwani, and A. Islam, "Production of biodiesel from palm oil using modified Malaysian natural dolomites," Energy Conversion and Management, vol. 78, pp. 738-744, 2014.

[19] S. Jaiyen, T. Nareeb, and C. Ngamcharussrivichai, "Comparative study of natural dolomitic rock and waste mixed seashells as heterogeneous catalysts for the methanolysis of palm oil to biodiesel," Renewable Energy, vol. 74, pp. 433-440, 2015.

[20] S.-L. Niu, M.-J. Huo, C.-M. Lu, M.-Q. Liu, and H. Li, "An investigation on the catalytic capacity of dolomite in transesterification and the calculation of kinetic parameters," Bioresource Technology, vol. 158, pp. 74-80, 2014.

[21] M. S. Shafeeyan, W. M. A. Wan Daud, A. Houshmand, and A. Arami-Niya, "The application of response surface methodology to optimize the amination of activated carbon for the preparation of carbon dioxide adsorbents," Fuel, vol. 94, pp. 465-472, 2012.

[22] G. Chen, J. Chen, C. Srinivasakannan, and J. Peng, "Application of response surface methodology for optimization of the synthesis of synthetic rutile from titania slag," Applied Surface Science, vol. 258, no. 7, pp. 3068-3073, 2012.

[23] R. C. R. Santos, R. B. Vieira, and A. Valentini, "Monitoring the conversion of soybean oil to methyl or ethyl esters using the refractive index with correlation gas chromatography," Microchemical Journal, vol. 109, pp. 46-50, 2013.

[24] S. Karimipour, R. Gerspacher, R. Gupta, and R. J. Spiteri, "Study of factors affecting syngas quality and their interactions in fluidized bed gasification of lignite coal," Fuel, vol. 103, pp. 308320, 2013.

[25] K. Shibata, T. Kiyoura, and Y. Hayashi, "Acid property and catalytic activity of silica gel treated with ammonium salts," Journal of the Research Institute for Catalysis, vol. 19, pp. 29-34, 1971.

[26] H. M. Rietveld, "A profile refinement method for nuclear and magnetic structures," Journal of Applied Crystallography, vol. 2, pp. 65-71, 1969.

[27] D. A. Constantinou, J. L. G. Fierro, and A. M. Efstathiou, "A comparative study of the steam reforming of phenol towards $\mathrm{H}_{2}$ production over natural calcite, dolomite and olivine materials," Applied Catalysis B: Environmental, vol. 95, no. 3-4, pp. 255-269, 2010.

[28] I. Noshadi, N. A. S. Amin, and R. S. Parnas, "Continuous production of biodiesel from waste cooking oil in a reactive distillation column catalyzed by solid heteropolyacid: optimization using response surface methodology (RSM)," Fuel, vol. 94, pp. 156164, 2012.

[29] M. Kouzu and J. S. Hidaka, "Transesterification of vegetable oil into biodiesel catalyzed by CaO: a review," Fuel, vol. 93, pp. 1-12, 2012.

[30] E. S. Umdu, M. Tuncer, and E. Seker, "Transesterification of Nannochloropsis oculata microalga's lipid to biodiesel on $\mathrm{Al}_{2} \mathrm{O}_{3}$ supported $\mathrm{CaO}$ and $\mathrm{MgO}$ catalysts," Bioresource Technology, vol. 100, no. 11, pp. 2828-2831, 2009. 
[31] J. M. Montero, D. R. Brown, P. L. Gai, A. F. Lee, and K. Wilson, "In situ studies of structure-reactivity relations in biodiesel synthesis over nanocrystalline MgO," Chemical Engineering Journal, vol. 161, no. 3, pp. 332-339, 2010.

[32] V. Mahdavi and A. Monajemi, "Optimization of operational conditions for biodiesel production from cottonseed oil on $\mathrm{CaO}-\mathrm{MgO} / \mathrm{Al}_{2} \mathrm{O}_{3}$ solid base catalysts," Journal of the Taiwan Institute of Chemical Engineers, vol. 45, no. 5, pp. 2286-2292, 2014.

[33] S. Gryglewicz, "Rapeseed oil methyl esters preparation using heterogeneous catalysts," Bioresource Technology, vol. 70, no. 3, pp. 249-253, 1999.

[34] T. Issariyakul and A. K. Dalai, "Biodiesel from vegetable oils," Renewable and Sustainable Energy Reviews, vol. 31, pp. 446-471, 2014.

[35] A. C. Alba-Rubio, M. L. A. Castillo, M. C. G. Albuquerque, R. Mariscal, C. L. Cavalcante Jr., and M. L. Granados, "A new and efficient procedure for removing calcium soaps in biodiesel obtained using $\mathrm{CaO}$ as a heterogeneous catalyst," Fuel, vol. 95, pp. 464-470, 2012. 

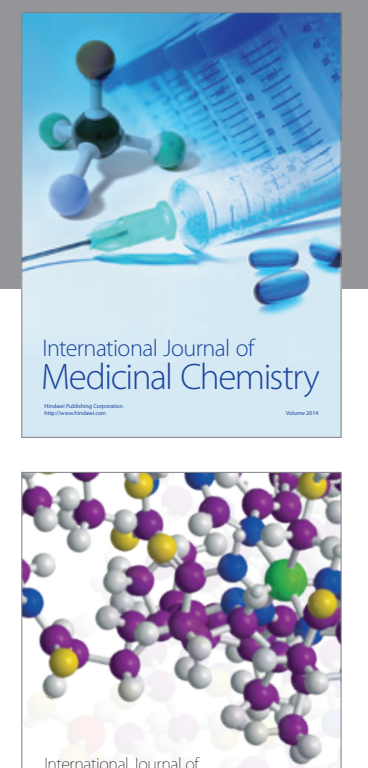

\section{Carbohydrate} Chemistry

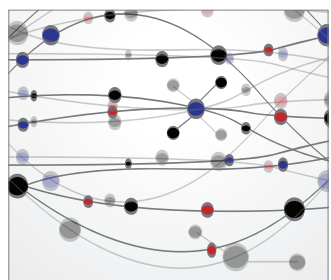

The Scientific World Journal
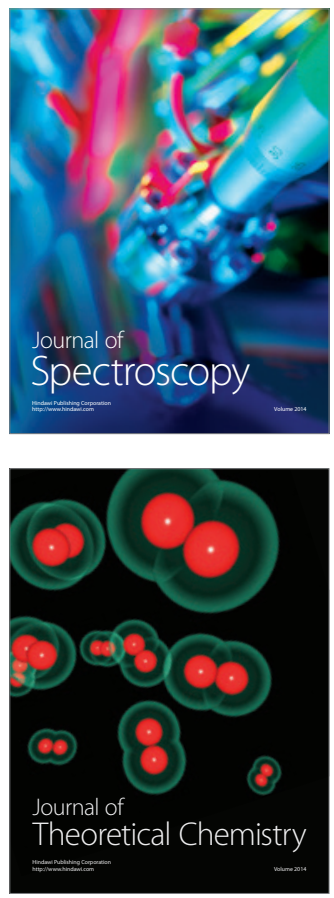
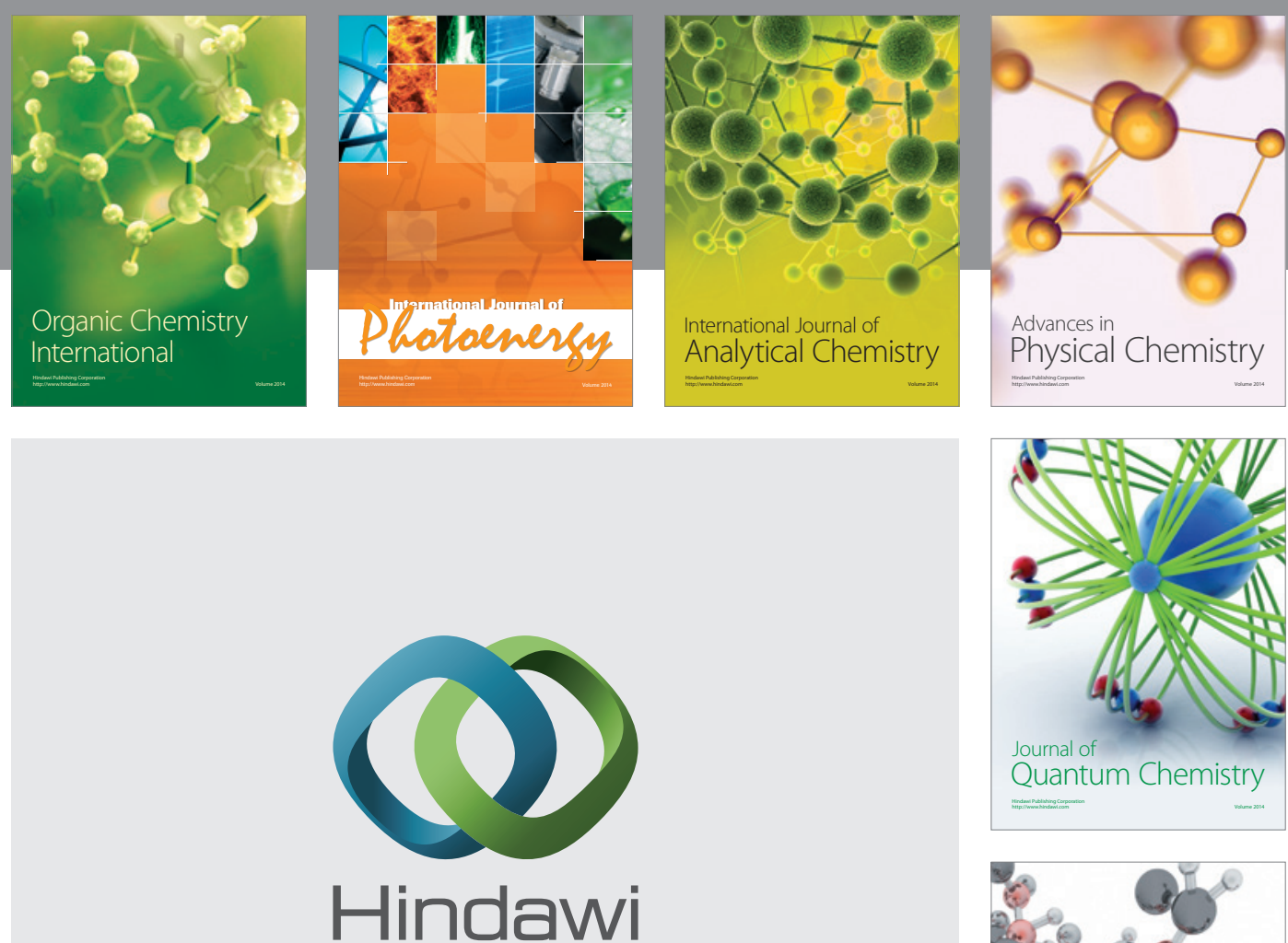

Submit your manuscripts at

http://www.hindawi.com

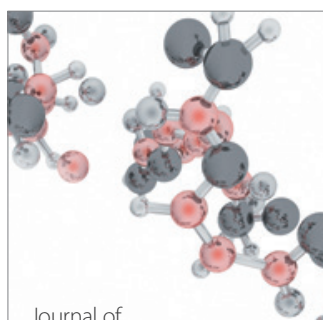

Analytical Methods

in Chemistry

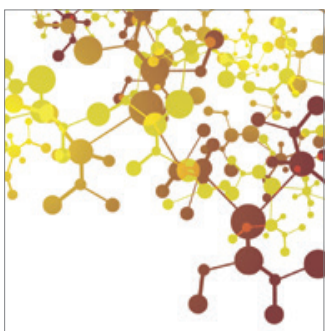

Journal of

Applied Chemistry

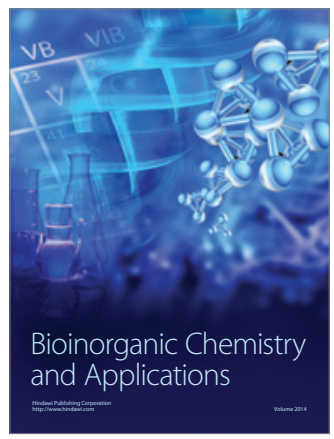

Inorganic Chemistry
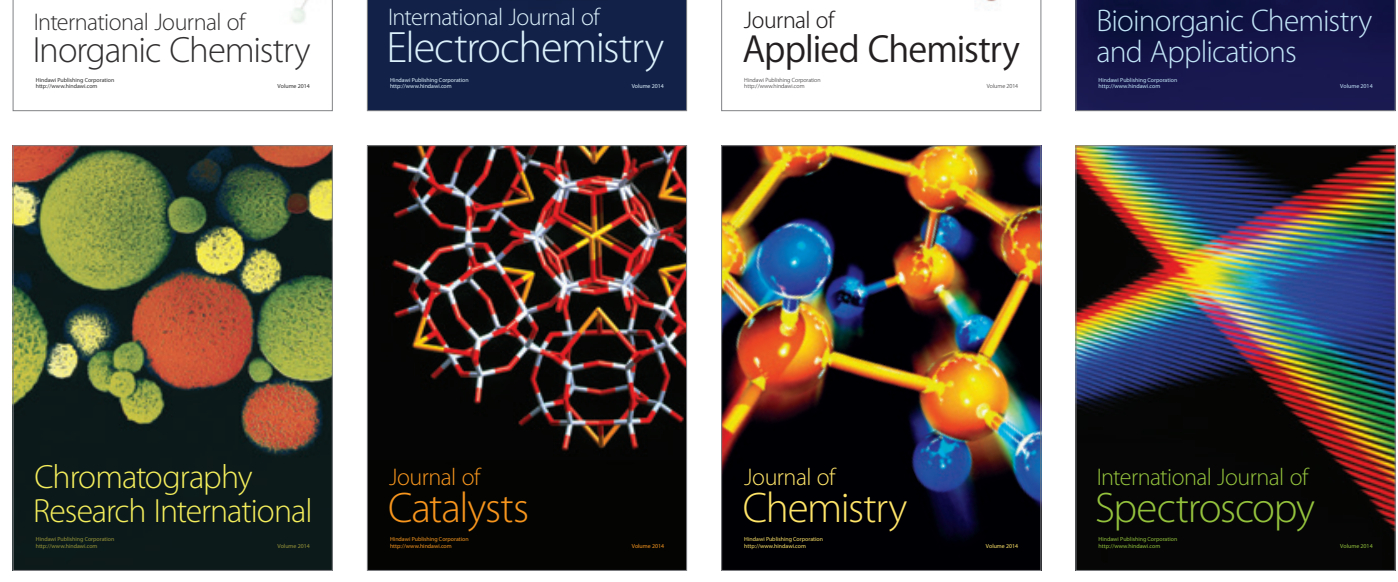